\title{
PENGARUH PERBEDAAN KANDANG TERHADAP PRODUKTIFITAS AYAM PETELUR FASE GROWER
}

\author{
Agustina Widyasworo, K., Edy Trijana S.
}

Dosen Fakultas Peternakan Universitas Islam Balitar

\begin{abstract}
Penelitian di laksanakan di peternakan di peternakan ayam petelur tipe ayam petelur Lohmann Brow produksi dari Jakfa konfeed Sidoarjo milik Bapak Mujito Farm, Desa Pikatan, Kecamatan Wonodadi, Kabupaten Blitar, mulai tanggal 23 juli hingga 23 agustus 2013. Tujuan dari penelitian ini adalah Untuk mengetahui perbedaan kandang terhadap produktivitas ayam petelur fase grower yang meliputi pertambahan bobot badan, mortalitas, sisa pakan ayam petelur fase grower.

Materi yang di gunakan adalah ayam petelur fase grower umur 8 minggu, sebanyak 200 ekor di tempatkan dalam wadah kandang baterai sebanyak 100 ekor dan kandang postal sebanyak 100 ekor,dengan bobot badan awal 680 gr/ekor yang di pelihara selama 30 hari serta pemberian pakan sebesar 58 gr/ekor per hari. Pakan yang di gunakan adalah Kosentrat KBR- 1 di produksi PT. Wonokoyo Jaya Corp Surabaya, Jagung, dedak halus, dan bahan pendukung (premix,mineral,anti jamur). Metode yang di gunakan adalah metode percobaan lapang dengan menggunakan membandingkan dua kandang yang berbeda dengan menggunakan uji $\mathrm{T}$. Apabila terdapat perbedaan pengaruh terhadap yang di amati adalah pertambahan bobot badan (gr/ekor), mortalitas ( /ekor), Konversi pakan( gr/ekor). Kandang yang di gunakan adalah kandang baterai sebanyak 50 unit kandang dan kandang postal sebanyak 10 unit kandang.

Hasil penelitian menunjukan bahwa perbedaan kandang terhadap pertambahan berat badan (PBB)ayam petelur fase grower denga perhitungan Uji t memberikan pengaruh yang sangat nyata $(<0,05)$ terhadap pertambahan berat badan $(\mathrm{PBB})$ yaitu kandang baterai $1150 \pm 68,31$ dan kandang postal $1089 \pm 7360$, , konversi pakan yaitu kandang baterai $1,3597 \pm 0,50$ dan kandang postal $1,6203 \pm 0,50$, mortalita untuk mortalitas hanya terjadi kanibalisme. Hal ini di karenakan perbedaan kandang baterai dan postal meliputi ukuran kandang yang berbeda, aktifitas ayam dalam kandang, perlakuan tiap kandang, populasi ayam tiap kandang, kelembapan udara, konversi pakan yang di konsumsi tiap ekor.

Dismpulkan semakin sedikit aktifitas ayam petelur fase grower maka energi yang di konsumsi dari pakan yang di berikan akan sedikit yang terbuang.

Untuk memperoleh penampilan yang yang paling baik di sarankan menggunakan kandang sistem baterai pada ayam petelur fase grower, serta perlu adanya perhatian mengenai ukuran kandang dan populasi di setiap kandang,selain memudahkan pengonterolan ternak untuk selalu melakukan penimbangan berat badan di akhir umur ayam, dan konversi pakan tiap minggu umur ayam, perkembangan berat badan ayam dapat cepat terpantau.
\end{abstract}

Kata kunci : Kandang Ayam Petelur, produktivitas 


\section{PENDAHULUAN}

Dewasa ini, pemelihara ternak unggas semakin meningkat, tidak hanya dikalangkan para peliharaan saja, tetapi masyarakat luas pun mulai menggemari ternak ini, dalam hal ini peternakan ayam petelur merupakan bagian yang tidak terpisahkan dari pembangunan sektor peternakan, Hal ini dapat di lihat dengan perkembangan kebutuhan daging dan telur ternak ayam petelur yang semakin meningkat dari tahun ke tahun. Badan Pusat Statistik Indonesia (2014), mencatat data kebutuhan daging ternak ayam petelur dari tahun 2010 sampai tahun 2013 di lihat pada tabel di bawah :

Tabel 1. Kebutuhan daging ayam petelur dari tahun 2010-2013

\begin{tabular}{|c|c|}
\hline Tahun & Kebutuhan Kaging /kapita \\
\hline 2010 & 57.717 .000 \\
\hline 2011 & 62.146 .000 \\
\hline 2012 & 66.050 .000 \\
\hline 2013 & 77.134 .000 \\
\hline
\end{tabular}

Sumber : Data BPS yang di olah (2014).

Badan Pusat Statistik Indonesia (2014), mencatat data kebutuhan telur ternak ayam petelur dari tahun 2010 sampai tahun 2013 di lihat pada tabel di bawah :

Tabel 1. Kebutuhan telur ayam petelur dari tahun 2010-2013

\begin{tabular}{|c|c|}
\hline Tahun & Kebutuhan Telur /kapita \\
\hline 2010 & 945.637 .000 \\
\hline 2011 & 1.027 .846 .000 \\
\hline 2012 & 1.139 .949 .000 \\
\hline 2013 & 1.224 .402 .000 \\
\hline
\end{tabular}

Sumber : Data BPS yang di olah (2014).

Data di atas menunjukkan bahwa dalam rentan waktu tiga tahun terakhir terjadi peningkatan yang signifikan kebutuhan daging dan telur peternakan ayam petelur di Indonesia.

saat ini dalam usaha ternak ayam ras petelur mempunyai tujuan untuk diutamakan memenuhi kebutuhan telur, dan menghasilkan daging yang berasal ayam petelur afkir yang dijual di pasar konsumen, dalam mewujudkan kesejahteraan masyarakat ( Abidin, 2003 ).

Oleh sebab itu guna meningkatkan peternakan di dalam keberhasilan usaha peternakan ditentukan oleh tiga faktor yaitu bibit, pakan dan manajemen pemeliharaan. Ketiga faktor tersebut merupakan satu kesatuan yang sangat berpengaruh terhadap keberhasilan usaha peternakan unggas, dimana masing-masing faktor berperan sebesar $20 \%$ bibit, 30\% pakan dan manajemen sebesar 50\% (Aziz dan Dian, 2007).

Menurut Johari (2003) periode grower adalah ayam yang berumur 5 sampai 12minggu, pada fase ini kontrol pertumbuhan dan keseragaman perlu dilakukan, hal ini berhubungan dengan sistem reproduksi dan produksi ayam tersebut, pada periode grower sistem produksi ayam mulai tumbuh dan sistem hormon reproduksi mulai berkembang dengan baik, berkaitan dengan berkembangnya sistem reproduksi, pada priode ini secara fisik tidak mengalami perubahan yang berarti, perubahan hanya dari ukuran tubuhnya yang semakin bertambah dan bulu yang semakin lengkap serta kelamin sekunder yang mulai nampak. 
Salah satu faktor yang kurang diperhatikan oleh peternak adalah pengawasan dan pengontrolan pada faktor manajemen, yaitu pengontrolan bobot badan baik di lakukan dengan pemeliharaan menggunakan sistem kandang yang berbeda akan memberikan pengaruh terhadap peroduktifitas dari ayam petelur tersebut. Peternak jarang yang memperhatikan bobot badan awal pemeliharaan. Untuk mengetahui tingkat pertumbuhan dari unggas apakah sudah sudah sesuai dengan standar dari strainnya atau tidak, maka perlu dilakukan penimbangan secara rutin (Prayitno dan Yuwono, 1999).

Pembangunan kandang harus memperhatikan faktor biologis dan faktor ekonomis. Selain itu pembangunan juga pertimbangan modal, sekala pemeliharaan, teknologi yang di terapkan, keterampilan pekerja, (Mutiara 2010).Tujuan penelitian ini adalah untuk mengetahui PBB ayam petelur fase grower dengan perbedaan sistem kandang. Untuk mengetahui mortalitas ayam petelur fase grower dengan perbedaan sistem kandang. Untuk mengetahui konversi pakan ayam petelur fase grower dengan sistem kandang yang berbeda.

\section{MATERI DAN METODE}

\section{Lokasi dan Waktu Penelitian}

Penelitian dilaksanakan di peternakan ayam petelur milik Bapak Mujito Farm di Dusun Gendis RT 04. RW 06, Desa Pikatan, Kecamatan Wonodadi, Kabupaten Blitar. Dan di laksanakan selama 4 minggu pada tanggal 23 juli hingga 23 agustus 2014. Dengan pertimbangan karena peternakan Bapak Mujito Farm sudah berdiri cukup lama selain itu mempunyai recording yang lengkap dan juga Bapak Mujito Farm selalu ingin mengikuti perkembangan dunia peternakan khususnya unggas.

\section{Materi penelitian}

Materi yang digunakan pada penelitian ini adalah sebagai berikut:

a. 200 ekor ayam ras tipe petelur fase grower strain Lohman produksi PT. Panca Patriot Prima umur 7 minggu sampai 12 minggu, 100 ekor di tempatkan di kandang bateray, dan 100 ekor di tempatkan di kandang postal.

b. Pakan konsentrat khusus yang diberikan untuk ayam petelur fase grower dengan kode produksi KBR-1 dengan di produksi oleh PT. Wonokoyo Jaya Corp Surabaya. Pakan yang di berikan merupakan campuran konsentrat, jagung, dan bekatul dengan perbandingan 3 : $5: 2$ yang di berikan sebanyak 2 kali sehari.

c. Air minum diberikan secara adlibitum dengan menggunakan (sistem nipple).

\section{Peralatan yang digunakan adalah :}

Alat yang digunakan pada penelitian ini adalah sebagai berikut:

a. Kandang sistem baterai dan kandang sistem postal terbuat dari bambu.

Kandang baterai yang berbentuk kotak diletakkan pada lantai dan disusun secara bertingkat dengan ukuran untuk kandang baterai setiap petak adalah panjang $(\mathrm{P})=30 \mathrm{~cm}$ lebar $(1)=33 \mathrm{~cm}$ dan tinggi depan $(\mathrm{T})=37 \mathrm{~cm}$, tinggi belakang $(\mathrm{T})=30 \mathrm{~cm}$ dengan bagian atas tertutup, kandang baterai keseluruan $(P)=200 \mathrm{~cm}$ terbagi menjadi 6 lokal dan masing-masing lokal dapat diisi 2 ekor ayam. 


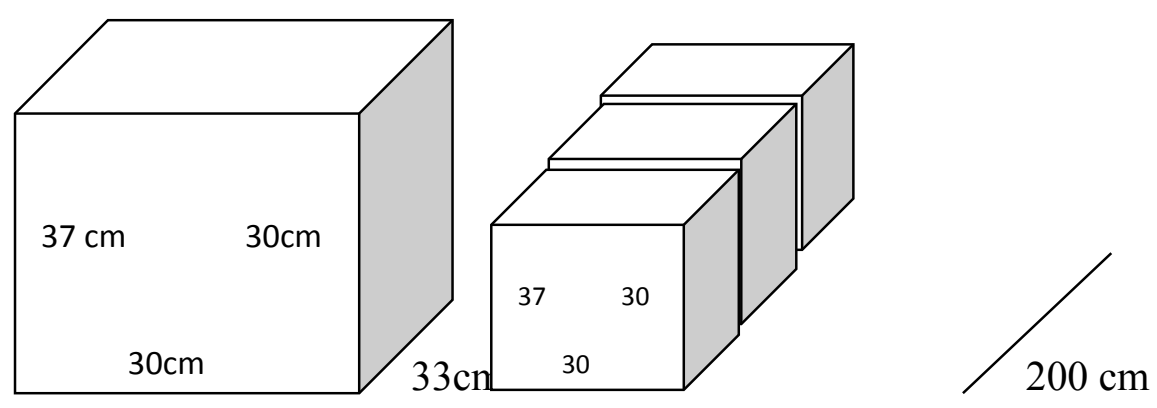

b. Kandang postal disediakan yaitu di bagi 10 petak kandang, tiap petak dengan ukuran luas kandang $(\mathrm{L})=1,5 \mathrm{~m}$ untuk kandang postal panjang $(\mathrm{P})=150 \mathrm{~cm} \quad$ lebar $(\mathrm{l})=100 \mathrm{~cm}$ ,untuk kandang postal berisi 10 ekor ayam.

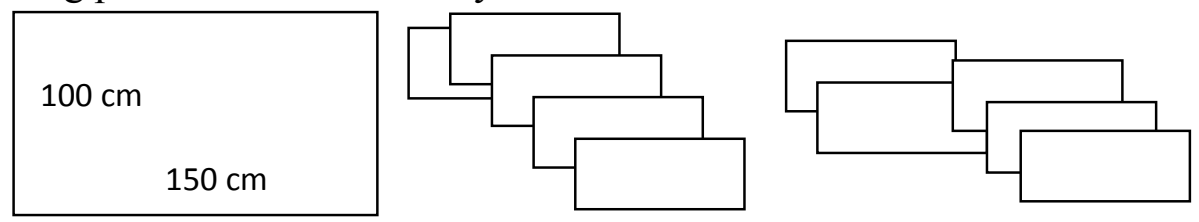

d. Tempat pakan yang berbentuk silinder yang terbuat dari pipa paralon yang di belah menjadi dua dengan ukuran $6 \mathrm{~cm}$ dan tinggi $5 \mathrm{~cm}$.

e. Thermometer suhu.

f. Timbangan pakan $15 \mathrm{~kg}$.

g. Timbangan ayam corong (scales punnel) yang digunakan untuk menimbang bobot badan ayam grower pada saat awal penempatan dan akhir.
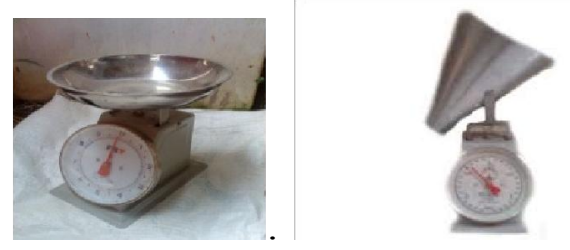

\section{Metode Penelitian}

Metode yang digunakan pada penelitian ini adalah metode percobaan dengan 2 perlakuan masing - masing dengan 1 ulangan, sebagai berikut :

a. Perlakuan 1 (P1) menggunakan media alas baterai.

b. Perlakuan 2 (P2) menggunakan media alas postal.

\section{Variabel Penelitian}

Variabel yang diamati dan cara pengukuran :

a. Jumlah ayam, dilakukan dengan cara:

Menghitung jumlah ayam secara keseluruhan baik yang hidup maupun yang mati.

b. Pertambahan bobot badan, dilakukan dengan cara :

Menimbang yang ditempatkan pada wadah tertentu yang sudah ditimbang terlebih dahulu berat dari wadah tersebut, kemudian dilakukan penimbangan secara bergantian. Hasil penimbangan bobot badan akan dikurangi dengan berat wadah yang digunakan untuk tempat menimbang, penimbangan di lakukan satu minggu sekali. 
c. Mortalitas

Tingkat mortalitas ayam dapat ditentukan dari jumlah ayam yang mati selama penelitan dibagi jumlah ayam awal dikalikan $100 \%$. Pengamatan kematiaan ayam dilakukan setiap hari selama penelitian.

d. Konversi pakan

adalah jumlah pakan yang di berikan di kurangi dengan sisa pakan per ekor ayam, penimbangan pakan di lalukan tiap hari dan sisa pakan akan ditimbang lagi sehingga memperoleh hasil yang di harapkan.

\section{Analisis Data}

Dalam penelitian ini data yang di proleh di analisis dengan menggunakan uji t. Dengan rumus sebagai berikut( Zulaika, 2007)

$$
\begin{array}{ll}
\text { Hipotesis : } & \begin{array}{l}
\mathrm{H}_{0}: \overline{\mathrm{A}}=\mathrm{B} \\
\mathrm{H}_{1}: \overline{\mathrm{A}} \neq \mathrm{B}
\end{array} \\
\text { t hitung } & =\frac{|\overline{\mathrm{A}}-\mathrm{B}|}{\mathrm{S}} \\
& (\overline{\mathrm{A}}-\mathrm{B}) \\
\mathrm{S}_{\mathrm{A}} & =\frac{\mathrm{JK} \mathrm{A}}{\mathrm{A}} \\
\mathrm{S}_{\mathrm{A}}^{2} & =\frac{\mathrm{JK} \mathbf{B}}{\mathrm{B}} \\
& =\sqrt{\frac{\mathbf{S}^{2}}{\mathrm{n}_{\mathrm{A}}}}+\frac{\mathbf{S}^{\mathbf{2}} \mathbf{B}}{\mathrm{n}_{\mathrm{B}}}
\end{array}
$$

Berat Badan

Jika t hitung $<$, atau $=\mathrm{t}$ table maka $\mathrm{H}_{0}$ di terima, perlakuan tidak ada perbedaan

Jika $\mathrm{t}$ hitung $>$, atau $=\mathrm{t}$ table maka $\mathrm{H}_{0}$ di terima, perlakuan ada perbedaan

Rumus perhitungan FCR $=\sum$ pakan

Alasan kenapa memakai Uji t adalah Uji t yang terdiri dari dua peubah bebas (Faktor) yang berbeda dalam klasfikasi silang yaitu faktor A yang terdiri dari 1 taraf dan faktor B yang terdiri dari 1 taraf dan kedua faktor tersebut diduga saling berinteraksi.

\section{HASIL DAN PEMBAHASANPengaruh Perlakuan terhadap Pertambahan Berat Badan (PBB)}

Data rata-rata produktifitas pertambahan berat badan ayam petelur fase grower selama penelitian dapat di lihat pada tabel di bawah.

Tabel 1. data rata-rata produktifitas pertambahan berat badan ayam petelur fase grower selama penelitian sebagai berikut.

\begin{tabular}{|l|l|}
\hline Perlakuan & PBB (gr) \\
\hline Kandang baterai & $5374,7 \pm 444,66$ \\
\hline Kandang postal & $4958 \pm 510,58$ \\
\hline
\end{tabular}

Sumber : Data pribadi diolah, 2014 
Dari hasil penelitian secara lengkap di sajikan pada tabel 1. Rataan konversi pakan tertinggi sampai terendah berturut -turut yaitu adalah kandang sistem baterai $5374,7 \pm$ $444,66 \mathrm{kandang}$ sistem postal nilai rata-rata sebesar $4958 \pm 510,58$. Untuk mengetahui pengaruh perlakuan maka di lakukan analisis statistika.

Hasil analisis statistik pada lampiran 4 menunjukkan bahwa perbedaan kandang memberikan pengaruh yang nyata $(\mathrm{P}<0,05)$ terhadap pertambahan berat badan $(\mathrm{PBB})$ ayam petelur fase grower,atau $t$ hitung $>0,05(99)$ dengan ukuran kandang yang seperti di lakukan percobaan tersebut, 0.05 artinya dalam penelitian terdapat perbedaan $95 \%$ sehingga semakin tinggi persentasinya ,hasil dari penelitian tersebut semakin nyata hasilnya. PBB ada perbedaan dalam kenaikan berat badan untuk kandang sistem yang berbeda, hal ini dikarenakan perbedaan ukuran kandang untuk kandang baterai 200x30x37cm dan kandang postal 100x150 cm, perbedaan jumlah populasi tiap kandang untuk kandang baterai terdiri dari 2 ekor ayam dan kandang postal terdiri 10 ekor ayam ,dan banyaknya aktifitas tiap ayam sehingga energi yang di keluarkan untuk kandang baterai sedikit aktifitas dan banyak makan, dan kandang postal banyak melakukan aktifitas sedikit makan sehingga sehingga energi yang di serap tubuh,banyak yang terbuang untuk melakukan aktifitas.

Hal tersebut sesuai dengan pendapat (Indarto, 1990) ukuran luas sangkar kandang untuk satu ekor ayam adalah panjang $120 \mathrm{~cm}$, lebar $30-41 \mathrm{~cm}$ dan tinggi $30-37 \mathrm{~cm}$, kandang terbagi menjadi empat lokal dan masing - masing lokal dapat diisi 1-2 ekor ayam . Pintu kandang terletak di bagian muka, pada sisi yang berukuran $40-45 \mathrm{~cm}$ x $25-30 \mathrm{~cm}$.

Pendapat Ferry Tamalluddin,(2012) kandang postal Kebutuhan luas kandang per meter persegi adalah untuk 5-8 ekor ayam. Tebal litter setinggi $10 \mathrm{~cm}$, bahan litter dipakai campuran dari kulit padi/sekam dengan sedikit kapur dan pasir secukupnya, atau hasi serutan kayu dengan panjang antara 3-5 cm untuk pengganti kulit padi/sekam, kebutuhan luas kandang per meter persegi adalah untuk 5-8 ekor ayam.

Menurut Moritz et al,(2002) salah satu yang mempengaruhi besar kecil PBB adalah konsumsi pakan. Faktor utama yang mempengaruhi pertambahan berat badan adalah jumlah pakan yang di konsumsi dan jumlah zat makanan dalam pakan. Dengan terpenuhi konsumsi pakan zat makanan, maka konsumsi memiliki korelasi positif terhadap PBB. Semakin tinggi konsumsi pakan, menyebabkan semakin tinggi pula PBB. Semakin rendah konsumsi pakan, maka menyebabkan semakin rendahnya PBB.

Kandang dan ternak ibarat dua sisi mata uang yang tidak dapat di pisahkan satu sama lain. Kandang merupakan rumah atau tempat yang di fungsikan untuk tempat berlindung bagi ayam, tempat melakukan aktifitas produksi, dan reproduksi serta tempat memberikan jaminan perlindungan bagi ternak dari berbagai gangguan binatang buas (Mutiara hikmah, 2010).

Pembangunan kandang harus memperhatikan faktor biologis dan faktor ekonomis. Selain itu pembangunan juga pertimbangan modal, sekala pemeliharaan, teknologi yang di terapkan, keterampilan pekerja dan selera pemilik( Ahmadi,2008).

\section{Pengaruh Perlakuan terhadap Mortalitas}

Data rata-rata produktifitas Mortalitas ayam petelur fase grower selama penelitian dapat di lihat pada tabel di bawah.

Tabel 2. data rata-rata produktifitas mortalitas ayam petelur fase grower selama penelitian sebagai berikut.

\begin{tabular}{|l|l|}
\hline Perlakuan & Mortalitas \\
\hline
\end{tabular}




\begin{tabular}{|l|l|}
\hline Kandang baterai & 0 \\
\hline Kandang postal & 0 \\
\hline
\end{tabular}

Sumber : Data pribadi diolah, 2014

Dari hasil penelitian secara lengkap di sajikan pada tabel 3. Rataan konversi pakan tertinggi sampai terendah berturut -turut yaitu adalah kandang sistem baterai 0 dan kandang sistem postal nilai rata-rata sebesar 0 . Untuk mengetahui pengaruh perlakuan maka di lakukan analisis statistika.

Hasil statistika menunjukan bahwa perbedaan kandang tidak meberikan pengaruh yang nyata terhadap mortalitas antara kandang sistem baterai dan kandang postal tidak ada perbedaan di karenakan kedua kandang tersebut selama penelitian hari 1 sampai 30 tidak ada yang mati namun selama dalam penelitian terdapat kanibalisme yaitu untuk kandang baterai 0 ekor dan kandang postal 3 ekor ayam hal ini karena perbedaan ukuran kandang, jumlah ayam dalam kandang dan meningkatnya suhu lingkungan sehingga terjadi kanibalisme. Tingkat mortalitas ayam dapat ditentukan dari jumlah ayam yang mati selama penelitan dibagi jumlah ayam awal dikalikan $100 \%$. Pengamatan kematiaan ayam dilakukan setiap hari selama penelitian.

Mortalitas adalah jumlah ayam yang mati hari itu dibagi jumlah ayam mula-mula kali $100 \%$. Hal ini dapat berasal dari dalam peternakan sendiri seperti penyakit, manajemen yang salah, cuaca dan cekaman panas sedangkan dari luar peternakan seperti racun yang terkandung didalam pakan atau ransum (Cahyono 1995).

\section{Pengaruh Perlakuan terhadap Konversi Pakan}

Data rata-rata produktifitas Mortalitas ayam petelur fase grower selama penelitian dapat di lihat pada tabel di bawah.

Tabel 2 . data rata-rata produktifitas mortalitas ayam petelur fase grower selama penelitian sebagai berikut.

\begin{tabular}{|l|l|}
\hline Perlakuan & Konversi pakan \\
\hline Kandang baterai & $1,3597 \pm 0,50$ \\
\hline Kandang postal & $1,6203 \pm 0,50$ \\
\hline
\end{tabular}

Sumber : Data pribadi diolah, 2014

Dari hasil penelitian secara lengkap di sajikan pada tabel 2. Rataan konversi pakan tertinggi sampai terendah berturut -turut yaitu adalah kandang sistem baterai 1,3597 $\pm 0,50$ dan kandang sistem postal nilai rata-rata sebesar 1,6203 $\pm 0,50$. Untuk mengetahui pengaruh perlakuan maka di lakukan analisis statistika.

Hasil analisis statistic pada lampiran 4 menunjuk kan bahwa perbedaan kandang memberikan pengaruh yang nyata $(\mathrm{P}<0,05)$ atau $\mathrm{t}$ hitung $>0,05(29)$ terhadap konversi pakan ayam petelur fase grower dengan ukuran kandang yang seperti di lakukan percobaan tersebut, ,0.05 artinya dalam penelitian terdapat perbedaan $95 \%$ sehingga semakin tinggi persentasinya ,hasil dari penelitian tersebut semakin nyata hasilnya.. Dalam tabel dapat di ketahui bahwa untuk kandang baterai nilai rata-rata hal ini menunjukan bahwa konsumsi kandang sistem baterai lebih sedikit dan kandang postal lebih banyak dan untuk sisa konsumsi kebalikannya ,perbedaan FCR, perbedaan aktifitas antara kandang baterai sedikit aktifitas sehingga makan lebih banyak dan kandang sistem postal banyak aktifitas sehingga makan jadi berkurang. 
Hal ini sesuai dengan (Sudaermono, 2003) merupakan jumlah pakan yang di konsumsi di bagi berat badan,atau konversi pakan adalah jumlah pakan yang di konsumsi untuk membentuk $1 \mathrm{~kg}$ kultur daging per ekor ayam.

Konversi pakan merupakan perbandingan antara konsumsi pakan dengan PBB yang di hasilkan, sehingga nilai konsumsi pakan semakin tinggi namun pertambahan berat badan semakin rendah maka nilai konversi pakan akan lebih tinggi. Semakin kecil nilai konversi pakan maka akan semakin baik karena hal ini menunjukan bahwa penggunaan pakan semakin efisien ( Siregar dkk,1980)

Feed Conversi Rasio ( FCR ) merupakan salah satu indikator yang dapat memberikan gambaran tentang tingkat efisien ransum, semakin rendah nilai FCR, maka semakin tinggi tingkat efisiensi penggunaan ransumnya ( Anggorodi,1994)

sehingga akan di ketahui seberapa sisa paka yang di habiskan, untuk standar FCR ayam yaitu $0,7 \mathrm{~kg}$ semakin besar nilai FCR, maka semakin banyak pakan yang dibutuhkan untuk memproduksi $1 \mathrm{~kg}$ daging kultur sebaliknya semakin kecil nilai FCR, maka semakin sedikit pakan yang dibutuhkan untuk memproduksi $1 \mathrm{~kg}$ daging kultur.

\section{KESIMPULAN DAN SARAN}

\section{Mortalitas}

Berdasarkan hasil penelitian dapat di simpulkan bahwa perbedaan kandang baterai dengan kandang sistem postal terhadap pertambahan berat badan ( PBB ) ayam petelur fase grower yaitu dengan ukuran kandang panjang $(\mathrm{P})=30 \mathrm{~cm}$ lebar $(\mathrm{l})=33 \mathrm{~cm}$ dan tinggi depan $(\mathrm{T})=37 \mathrm{~cm}$, tinggi belakang $(\mathrm{T})=30 \mathrm{~cm}$, kandang baterai keseluruan $(\mathrm{P})=200 \mathrm{~cm}$ terbagi menjadi 6 lokal dan masing-masing lokal dapat diisi 2 ekor ayam dan sistem kandang postal, tiap petak dengan ukuran luas kandang $(\mathrm{L})=1,5 \mathrm{~m}^{2}$ untuk kandang postal panjang $(\mathrm{P})$ $=150 \mathrm{~cm}$ lebar $(\mathrm{l})=100 \mathrm{~cm}$, di bagi 10 petak kandang berisi 10 ekor ayam, perbedaan kandang terasebut terdapat perbedaan karena untuk pertambahan berat badan (PBB) $t$ hitung $>$ tabel 0.05(99) atau data rata-rata untuk kandang baterai nilai rata- rata sebesar $1150,2 \pm$ 68,31 , untuk kandang sistem postal sebesar nilai rata- rata $1089,4 \pm 73,60$, hal ini di karenakan perbedaan ukuran kandang dan banyaknya aktifitas di dalam kandang.

2. Konversi pakan

Untuk konversi pakan t hitung $>$ tabel $0.05(29)$ atau data rata-rata untuk kandang baterai nilai rata- rata sebesar 1,3597 $\pm 0,50$ dan kandang sistem postal nilai rata-rata sebesar $1,6203 \pm 0,50$, Untuk FCR nilai rata-rata kandang baterai 35 dan kandang postal 37, hal ini di karenakan perbedaan ukuran kandang,aktifitas kandang,dan perbedaan Fcr kandang.

3. Mortalitas

Kusus untuk mortalitas tidak ada perbedaan hal ini di karenakan tidak ada yang mati atau 0 mati tetapi terjadi kanibalisme di kandang postal sebanyak 3 ekor.

\section{DAFTAR PUSTAKA}

Abidin, Z. 2003. Meningkatkan Produktifitas Ayam Ras Petelur.Agromedia. Jakarta.

Ahmad dan Elfawati.2008.Performans Ayam Broiler yang Di Beri Sari Buahmdengkudu Http: // WWW.Uniska.Info/ faperta attchment/090/_Jurnal_ \%20tinal.pdf.Diakses tanggal 29 september 2014

Anggorodi, R. 1994 Ilmu Nutrisi Makanan Ternak Ruminansia. UGM Pres. Yogyakarta 
Ani Zulaika. 2007. Pengaruh Penambahan Protein pakan Berat Badan Ayam Petelur Masa pullet,Skripsi Uji $t$.jurnal aves vol 21-26 Fakultas Peternakan Universitas Islam Balitar.

Aziz dan Dian. 2007. Mengenal Ayam Petelur. CV. Sinar Cemerlang Abadi.

Ahmadi . 2005 . Beternak Ayam. CV.Gunung Mas. Pekalongan

Cahyono, B.1995. Cara Meningkatkan Budidaya Ayam Ras Pedaging(Broiler).

Pustaka Nusatama. Yogyakarta.

Indarto, 1990. Beternak Unggas Berhasil.Amico. Bandung.

Hartono, A.H.S. 1997. Beternak Ayam Petelur. CV. Gunung Mas. Pekalongan.

Haslly,Z,danA.N.Kuntono.2006. Pengaruh Perbaikan Kualitas danWaktuPemberian pakan Terhadap pertumbuhan

petelur.http//peternakan.litbang.deptan.go.id/publikasi/semnas/pdf

Indarto, P. 1990. Beternak Unggas Berhasil. CV. Armico. Bandung.

Johari, S. 2005. Sukses Beternak Ayam Ras Petelur. PT Agromedia pustaka.

Malik, A. 2001. Manajemen Ternak Unggas. Fakultas Peternakan Perikanan. Universitas Muhammadiyah Malang. Malang.

Morits,J. S. K . J. Wilson, K. R. Cramer, R. S. Bayer, L. J. McKinney, B. Cavalcatin, and X . Mo. 2002. Effect Of Formulation density, Maisture, and surfactan on Feed Manufacturing, Pullet Quali, and Bloiler Performance, Http: // japr.fass.org/egi/reprint/11/2/155. Diakse september 20014.

Mutiara Hikmah. 2010. Pengaruh pemanfaatan pakan terhadap penampilan produks itiki,Skripsi Uji $t$.jurnal aves vol 25-30 Fakultas Peternakan Universitas Brawijaya Malang.

N.G.K. Mulyantini.2010 .Ilmu Manajemen Ternak Unggas.Gadjah Mada University prees.Bulaksumur, Yogyakarta.

Prayitno, D.S., dan W.E. Yuwono.1999. Manajmen Kandang Ayam Ras Pedaging. PT. Trubus Agriwidya, Ungaran.Jakarta

Sudaermono. As. 2003. Pedoman Peliharaan Ayam Ras Petelur. Kanisius. Yogyakarta.Http//Kanisius media.com.www. Pemeliharaan Ayam Petelur :jurnal .Blok Spot di unduh tanggal 28 Juni 2014 